\title{
ACRL issues for the 90s
}

\section{ACRL's two presidential candidates offer their views on}

\section{the Association's future.}

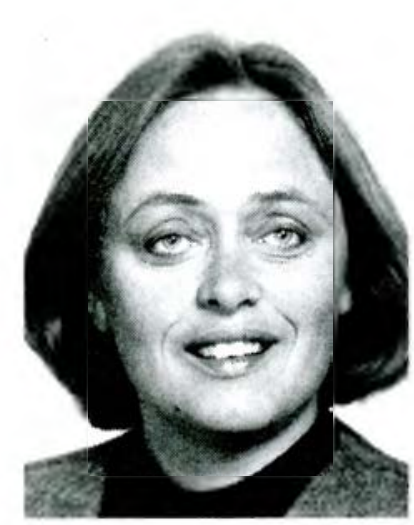

Barbara J. Ford

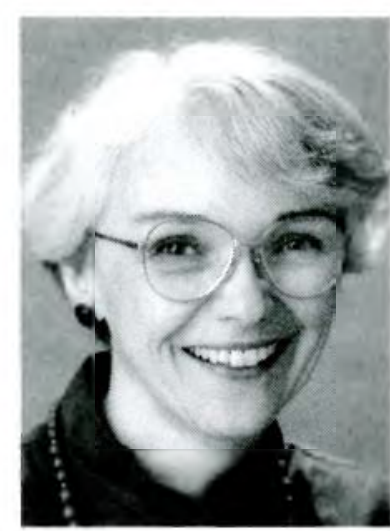

Patricia A. Wand
$\mathbf{T}$ his presentation of statements from ACRL's candidates for Vice-President/President-Elect is an information service for ACRL members. Many of the issues and concerns facing ACRL are discussed informally at meetings, but this does not provide a national forum available to all members. These statements provide the basis for an informed choice when you receive your ballot next month.

\section{Barbara J. Ford:}

ACRL is a lively, dynamic, and effective organization due to the work of members, elected and appointed officers, and staff. Building on the past, we must continue ACRL's leadership role as we make the planning and policy decisions which will carry us into the next century.

\section{Importance of librarians}

We must emphasize the importance of librarians in our academic institutions including our knowledge, experience, and advocacy relating to access to information, intellectual freedom, and censorship, and our role in preserving the records of culture and history. The two priorities the ACRL
Board has set for 1990 and 1991 are especially important. They are: continued advocacy and liaison work to make ACRL and academic librarianship more visible among academic administrators; and recruitment to the profession of academic librarianship.

Since libraries no longer have a monopoly on the collection and distribution of information, we need to develop inventive ways to effectively compete for scarce resources and to meet the challenges of technological developments. Librarians have unique skills and abilities to assist students, faculty, and staff to utilize resources in academic and research libraries. Efforts by ACRL to assure that librarians are recognized as full partners in the academic enterprise continue to be important.

\section{The role of $A C R L$}

ACRL must stay in the forefront of major professional issues and values such as access to information, library services, information literacy, legislative issues, intellectual freedom, social responsibility, and equal opportunity. ACRL must continue to be a catalyst for the development of library philosophies and ethics as well as of standards and guidelines for library practice and procedures.

Providing high quality professional development opportunities, including conferences, programs, journals, and other publications should continue as a priority. Using these vehicles, we need to seek innovative ways of addressing issues of concern such as the price of materials, changes in government publishing, technology, the recruitment and retention of quality librarians, and the changing and expanding role of libraries and librarians.

As an officer of ACRL I would actively work with all units of ACRL including chapters, sections, discussion groups, committees, editorial 
boards, and other units and serve as a speaker and advocate for academic libraries and librarians. Through appointments, I would work to increase the involvement of members who may offer innovative solutions to problems and deal directly with major issues confronting libraries and librarians. Upholding the values of the profession and association, and balancing between continuity and change as ACRL responds to changes in academic libraries and librarians, would be priorities.

Working with ACRL members, leadership, and staff, I would support the goals of ACRL outlined in the strategic plan. These goals are: contribute to the professional development of academic and research librarians; enhance the capability of librarians to serve the needs of users; promote and speak for the interests of librarianship; and promote study, research, and publication relevant to academic and research librarianship.

We also need to maintain and build links and connections to other units in ALA and higher education and support ALA's mission, priority areas and goals. In addition, I would focus attention on two other areas: international perspectives as technology and other political and economic forces remove national barriers; and education for library and information science.

\section{ACRL and ALA}

As a part of ALA, ACRL has the opportunity to build on the issues shared by librarians regardless of roles or functions or type of library. Within ALA we can support each other's efforts and work toward common priorities to provide better library service for all. Our challenge is to identify and pursue the choices that best serve the needs of our members.

As a major ALA division, with more than 10,000 members, we must balance membership priorities, financial considerations, and the needs of sections, chapters, and other groups. ACRL and ALA face challenges in allocating resources and addressing a variety of needs. Just as academic librarians should continue to utilize National Library Week, Banned Book Week, Freedom of Information Day, and other similar events to build coalitions, so should ACRL continue to work with other ALA units to forge cooperative efforts to work on mutual interests.

As libraries have sought new creative and effective means for providing services, so has ACRL. Strategic planning, financial planning, operating plans, adoption of marketing strategies, policy statements, and other techniques have been used effectively by ACRL officers and staff. While we cannot ignore internal politics and the ongoing issues of finance, we need to continue to reach beyond this to focus on emerging and substantive issues affecting the future of library programs and service and access to information.

\section{In conclusion}

I am honored to be part of a long and proud tradition of academic and research librarianship and to be nominated for office in ACRL. I have been involved in ACRL for a number of years and I have served as a member of the ALA Council for eight years. In ACRL and ALA I have worked on a variety of issues, including accreditation, bibliographic instruction, government documents, international relations, library education, membership, personnel, planning and budget, public services, social responsibilities, and status of women.

I welcome the opportunity to serve as president of ACRL as we address the challenges and opportunities facing ACRL and academic and research libraries and librarians in the years ahead.

Barbara J. Ford is Associate Director, Trinity University Library, San Antonio, Texas.

\section{Patricia A. Wand:}

As chair of the Budget and Finance Committee from 1986 to 1988, I served on the ACRL Board of Directors and the Executive Committee. Over the past decade, I have held offices in two sections, a chapter, several committees and have been a member of task forces and discussion groups. Currently I am also actively engaged at the University of Oregon Library with the challenges of offering all types of library services, selecting and training staff, developing well-rounded collections, planning building projects, and implementing an automated and integrated library system. From my perspective as an ACRL member and a practicing librarian, I see numerous issues facing us in the 1990s and will touch on some of the more prominent ones.

Issues facing the Association fall into two categories: those affecting most academic libraries in the U.S., and those particular to the operation of ACRL. Because ACRL attempts to deal with the professional needs of academic and research librarians as a whole, whether or not they are ACRL members, it must address both sets of issues.

\section{Issues generic to the profession}

In this set of issues I include those concerns shared by academic librarians even if they are not members of ACRL. Because ACRL attempts to represent all academic librarians, it must be alert to concerns of the profession as a whole and address them in some way.

The first issue is that of human resources for the profession. We must continue to develop new talent, to work for broader representation of all races and ethnic groups in the profession, to reward information providers who perform well, and to stay competitive with salaries.

This is the information age and more people than ever before are engaged in information- 
related occupations. Academic librarians have a unique opportunity to contribute: they combine technical skill and managerial expertise with a long tradition of providing information service. It is this combination that can put them into leadership positions in an academic community. The unfortunate fact is that many librarians themselves are unaware of their potential and hence are not actualizing it. Collectively we should work to expand our thinking about our roles.

This leads to a second issue: visibility. Other sectors within higher education frequently are unaware of the role of libraries in the scholarly communication process. ACRL has addressed this issue for many years and will continue to do so. It is one, like publicity for good library programs, that will never be finished; instead, it must be creatively approached with renewed vigor every year. We need to work in a variety of strategies to assure that professional organizations of other sectors in higher education include representation from libraries.

The third issue is the pace of technological development and its application to library service. The fundamental question is how can librarians continue to juggle the pressure on the one hand to maintain traditional services and formats and on the other to introduce new formats and enhance services utilizing new technology? Are we positioning ourselves well for technologically linking into the scholarly processes of the 1990s? Can ACRL do more to participate in the development of the scholarly workstation?

The rising cost of library materials constitutes the fourth issue. Every library is facing this serious problem and ACRL must face it too. How can ACRL act on behalf of its many members to modify this trend?

A final issue is that of operating our libraries in compliance with the Library Bill of Rights. This powerful document can serve as a mission statement for every academic library. The problems of censorship are always with us but because of technology, new services, rising costs of materials, and scarcity of publishing in certain areas, we are vulnerable in new ways.

\section{Issues particular to ACRL}

Although nearly transparent to the rank-and-file ACRL member, an important issue now being addressed is that of ACRL's relationship with its parent organization, the American Library Association. The "Operating Agreement" is being developed and encompasses nearly every aspect of the working relationship between ALA and its divisions, of which ACRL is the largest with over 10,000 members.

The agreement lists basic services provided by ALA as distinct from those offered by its divisions, and spells out who is financially responsible for each. It covers such management concerns as how dues revenue may be spent, what activities will be charged overhead, who underwrites which parts of
Midwinter Meetings and Annual Conferences, the disposition of division fund balances, who covers direct and indirect costs, and under what circumstances endowments may be established.

This analysis of ALA management concerns will affect the ACRL budget, which constitutes the second issue I wish to address. In 1987 the Budget and Finance Committee alerted the ACRL Board that revenue from dues was no longer able to support member activities and recommended that a task force be charged with exploring sources of revenue outside the dues structure. That task force met for the first time at the 1989 Midwinter Meeting in Washington, and I predict that its recommendations will figure prominently in budget planning during the coming years. The Board, at the same meeting, decided that the dues increase should appear on the ballot. The issue of sufficient revenue to underwrite the cost of the many programs of ACRL is very significant.

The third issue I see is that of the strategic plan. The five-year plan was approved by the ACRL Board, went into effect in 1986, and is due for review by 1991 . We have moved over half-way through its implementation and must begin to consider the methods by which it will be reviewed.

The fourth issue, which is closely linked to the member-driven strategic plan, involves meeting member needs. I see this as the single greatest challenge to ACRL. I refer to meeting needs of both inactive and active members. Inactive members are those who pay dues but initiate no other contact with ACRL. They work in libraries or related fields and need the support of a professional association even though they may not articulate that need on a regular basis. Active members pay dues, attend national or regional conferences, and participate in committee, section or chapter activities. These are the members who usually articulate the needs of the profession and simultaneously stimulate ideas for projects that cost money! The challenges are obvious: how to learn of the needs of inactive members and how to meet the needs of all members while operating within the budget.

\section{Western New York/Ontario Chapter Fall Conference}

On September 26, 1988, ACRL's Western New York/Ontario Chapter held its Fall Conference at the State University of New York at Buffalo. Nine papers were presented, one of which, by Joan Ormondroyd of Cornell on "Making Real Changes: Course-Intregrated Instruction," was the winner of an all-expenses paid trip to the ACRL National Conference in Cincinnati. Two runners-up and a door prize winner received free registrations.

The keynote speaker was JoAn S. Segal, ACRL executive director. 


\section{How am I prepared to address these issues?}

If I am elected to the position of vice-president, president-elect, I will depend heavily on ideas from members for ways in which we can meet the challenges of the 1990s. I am committed to the concept of a member-driven organization. At any time, I welcome comments and suggestions from members (active or inactive) about how ACRL can address these issues.
Because I have participated in every type of unit operating in ACRL, I understand fully how ACRL works. I also understand the importance of leadership to the organization. I am prepared to provide that leadership in addressing these issues and representing ACRL.

Patricia A. Wand is assistant university librarian for public services at the University of Oregon, Eugene.

\section{Libraries and telecommunications}

\section{technologies}

\author{
By Linda Bigelow \\ Project Consultant \\ Northern Illinois Learning Resources \\ Cooperative
}

\author{
and Alice Calabrese \\ Project Director \\ Northern Illinois Learning Resources \\ Cooperative
}

\section{A survey of the literature, with an emphasis on networks.}

$\mathbf{W}$ hat are the new telecommunications technologies and how well have they been adapted to the needs of libraries? These two questions were the focus of a recent survey of the literature as part of an LSCA Title III grant project funded by the Illinois State Library. The purpose of the grant was to research the requirements for a statewide library telecommunications network in Illinois.

\section{Telecommunications technology}

The convergence of telecommunications and technology was frequently cited in the literature as the driving force behind today's telecommunications trends. Goldstein (1988) saw this convergence as both "confusion and opportunity" (p.36). Noam (1987) described in detail the resulting shift in the concept of public telecommunications from a centralized, hierarchical, universally accessible network (characterized by AT\&T before divestiture) to "a new one that is open and loosely intercon- nected, resembling a federation of subnetworks much like the system prevailing in transportation" (p.30). The shift toward an information-based service economy has created great user demands for high-speed, low-cost telecommunications at the same time that decentralized services have reduced the former economies of scale that increased technological options are available.

West (1984) commented on the trend toward distributing powerful information processing capacity to individuals and connected this decentralization to "increasing demand to link this dispersed...power via a digitized, integrated (voice, video, and data) telecommunications network so that individuals can communicate with each other" (p.2).

The integration of voice, video, and data was one of the primary trends found in the literature. Integration was discussed on several levels. In 1984, West was calling for colleges and universities to work toward integration of communication 